\title{
Highly Halaven-resistant KBV20C Cancer Cells Can Be Sensitized by Co-treatment with Fluphenazine
}

\author{
JI HYUN CHEON, BYUNG MU LEE, HYUNG SIK KIM and SUNGPIL YOON \\ School of Pharmacy, Sungkyunkwan University, Suwon, Republic of Korea
}

\begin{abstract}
Aim: To identify conditions that induce an increase in the sensitivity of highly Halaven (HAL)-resistant cancer cells compared to sensitive cells. Materials and Methods: We observed that drug-resistant KBV2OC cells are highly resistant to HAL compared to other antimitotic drugs. The concentration required to treat KBV20C cells was almost 500-fold higher than that used to treat sensitive parent $K B$ cells. In order to increase sensitization, HAL-treated KBV20C cells were co-treated with the repositioned drug, fluphenazine (FLU). Results: HAL and FLU co-treatment inhibited the growth and increased apoptosis via $G_{2}$ arrest in HAL-treated KBV2OC cancer cells. Sensitization by HAL-FLU affected retinoblastoma protein $(p R B), p H i s t o n e ~ H 3$ and $p H 2 A X$ protein levels. FLU could also inhibit p-glycoprotein (P-gp) activity in HA-resistant KBV2OC cells. These observations suggest that the mechanisms underlying FLU-HAL sensitization in resistant KBV2OC cells involve both apoptosis and P-gp inhibition. Furthermore, both thioridazine (THIO) and mefloquine (MEF), but not azathioprine (AZA), sensitized HAL-treated KBV20C cells. Conclusion: These findings provide important information regarding the sensitization of $H A L$-resistant cells and indicate that FLU, THIO and MEF may have similar sensitization effects in highly HAL-resistant cells.
\end{abstract}

Antimitotic drugs, which target different binding sites on tubulin, are widely used for treating different cancers $(1,2)$. These compounds inhibit mitosis by targeting microtubules and preventing their polymerization or depolymerization (14). Halaven (HAL), also called eribulin, was recently

This article is freely accessible online.

Correspondence to: Hyung Sik Kim, Ph.D. and Sungpil Yoon, Ph.D., School of Pharmacy, Sungkyunkwan University, 2066 Seobu-ro, Jangan-gu, Suwon, Gyeonggi-do, 16419, Republic of Korea. Tel: +82 312907789, Fax: +82 312928800, e-mail: hkims@skku.edu,syoon88@gmail.com

Key Words: Halaven, fluphenazine, mefloquine, thioridazine, P-gp, drug-resistance. developed and used in the clinic to treat resistant or metastatic cancer. HAL has been developed to overcome the resistance of cancer cells to routinely used antimitotic drugs. HAL targets the depolymerization of microtubules $(5,6)$. HAL is considered a promising drug for triple-negative breast cancer or certain resistant cancers $(7,8)$. Since patients are expected to develop resistance to HAL, identifying the mechanism(s) that underlie cell sensitization to HAL would be an important step in the development of more effective treatments by designing approaches to increase HAL-associated apoptosis.

In the present study, we determined that P-glycoprotein (P-gp)-overexpressing KBV20C cells are highly resistant to HAL compared to their resistance to other antimitotic drugs. Fluphenazine (FLU) was used as a neuroleptic or anti-emetic agent $(9,10)$. However, FLU has been recently shown to inhibit P-gp and is considered an anti-cancer chemopreventive agent $(11,12)$. We then tested whether cotreatment using HAL and FLU increases the sensitivity of highly HAL-resistant KBV20C cells. We further investigated the mechanism underlying HAL-FLU sensitization using various apoptotic assays and molecular signatures to determine the factors involved in the effects observed in HAL-resistant cancer cells co-treated with HAL and FLU. Additionally, we tested whether co-treatment with thioridazine (THIO), azathioprine (AZA) or mefloquine (MEF) sensitized HAL-treated KBV20C cells. Since these drugs have already been approved for the treatment of humans (13), they, as repositioned drugs, could be readily available for clinical use once their anti-cancer activities are better understood. These results will contribute to the development of FLU-, THIO- and MEF-based therapy for co-treatment of cancer in highly HAL-resistant patients.

\section{Materials and Methods}

Reagents. FLU, THIO, MEF and verapamil (VER) were purchased from Sigma-Aldrich (St.Louis, MO, USA). AZA was purchased from Selleckchem (Houston, TX, USA). Vinblastine (VIB) was purchased from Enzo Life Sciences (Farmingdale, NY, USA). Aqueous solutions of HAL (Eisai Korea, Seoul, South Korea) were obtained from the National Cancer Center in South Korea. 
Antibodies. Antibodies against pGSK3 $\beta$, pHistone H3, proliferating cell nuclear antigen (PCNA) and cleaved-poly(ADP-ribose) polymerase (C-PARP) were from Cell Signaling Technology (Danvers, MA, USA). Antibodies against glyceraldehyde 3phosphate dehydrogenase (GAPDH), survivin and retinoblastoma protein $(\mathrm{pRb})$ were from Santa Cruz Biotechnology (Santa Cruz, CA, USA). Antibody against pH2AX was from Abcam (Cambridge, UK).

Cell culturing. Human oral squamous carcinoma cell lines, KB and its multidrug-resistant subline, KBV20C, were obtained from Dr. Yong Kee Kim (College of Pharmacy, Sookmyung Women's University, Seoul, Republic of Korea) and have been previously described (1416). All cell lines were cultured in RPMI 1640 containing $10 \%$ fetal bovine serum, $100 \mathrm{U} / \mathrm{ml}$ penicillin and $100 \mu \mathrm{g} / \mathrm{ml}$ streptomycin (WelGENE, Daegu, South Korea).

Microscopic observation. Cells grown in 6-well plates were treated with the indicated drugs for the indicated times. The medium was removed and PBS was added in each dish. Cells were examined in two independent experiments immediately using an Axio observer.Z1 fluorescence inverted microscope (Carl Zeiss, Oberkochen, Germany) with a $5 \times$ or $10 \times$ objective lens (Carl Zeiss EC Plan-Neofluar).

Fluorescence-activated cell sorting (FACS) analysis. FACS analysis was performed as previously described (17-19). Cells were grown in $60-\mathrm{mm}$ diameter dishes and treated with the indicated drugs for the prescribed times. The cells were then dislodged by trypsin and pelleted by centrifugation. The pelleted cells were washed thoroughly with PBS, suspended in $75 \%$ ethanol for at least $1 \mathrm{~h}$ at $4^{\circ} \mathrm{C}$, washed with PBS and re-suspended in a cold propidium iodide (PI) staining solution (100 $\mu \mathrm{g} / \mathrm{ml}$ RNase A and $50 \mu \mathrm{g} / \mathrm{ml}$ PI in PBS) for $30 \mathrm{~min}$ at $37^{\circ} \mathrm{C}$. The stained cells were analyzed in two independent experiments for relative DNA content using a FACSCalibur flow cytometry system (BD Bioscience, Franklin Lakes, NJ, USA).

Annexin $V$ analysis. Annexin $\mathrm{V}$ analysis was conducted using the annexin V-fluorescein isothiocyanate (FITC) staining kit (BD Bioscience) as previously described (17-19). Cells were grown in 60-mm diameter dishes and treated with the indicated drugs for the prescribed times. The cells were then dislodged by trypsin and pelleted by centrifugation. The pelleted cells were washed with PBS. Cells in $100 \mu \mathrm{l}$ of binding buffer received $5 \mu \mathrm{l}$ of Annexin VFITC and $5 \mu \mathrm{l}$ of PI and were, then, incubated for $15 \mathrm{~min}$ at room temperature. The stained cells were analyzed using a FACSCalibur flow cytometry system (BD Bioscience). Two independent experiments were performed.

Rhodamine and calcein-AM uptake tests. These tests were used for determination of ability for inhibition of P-gp using a previously described method (17-19). Briefly, cells grown in 6-well plates were treated with indicated drugs and incubated for $24 \mathrm{~h}$ at $37^{\circ} \mathrm{C}$. Cells were then incubated with and $1 \mu \mathrm{g} / \mathrm{ml}$ rhodamine or $0.1 \mu \mathrm{g} / \mathrm{ml}$ calcein-AM for $1 \mathrm{~h} 30 \mathrm{~min}$ at $37^{\circ} \mathrm{C}$. The medium was removed and the cells were washed with PBS. The stained cells were analyzed in two independent experiments using a FACSCalibur flow cytometry system (BD Bioscience).

Western blot analysis. Total cellular proteins were extracted using a previously described trichloroacetic acid (TCA) method (17-19).
Briefly, cells grown in 60-mm dishes were washed three times with $5 \mathrm{ml}$ PBS. Next, $500 \mu \mathrm{l}$ of $20 \%$ trichloroacetic acid (TCA) was added to each plate. The cells were then dislodged by scraping and transferred to Eppendorf tubes. Proteins were pelleted by centrifugation for $5 \mathrm{~min}$ at $3,000 \mathrm{rpm}$ and re-suspended in $1 \mathrm{M}$ Tris$\mathrm{HCl}(\mathrm{pH} 8.0)$ buffer. The total protein concentrations were estimated. The proteins were resolved by sodium dodecyl sulfatepolyacrylamide gel electrophoresis (SDS-PAGE) and subjected to Western blot analysis as previously described (17-19).

\section{Results}

KBV20C cells, highly resistant to HAL, are sensitized by FLU co-treatment. KBV20C cells present an antimitotic drugresistant phenotype via $\mathrm{P}$-gp overexpression (14-16). When testing the degree of resistance of KBV20C cells to HAL, we determined that KBV20C cells are highly resistance to HAL. In fact, in KBV20C cells, the necessary concentration of HAL required to observe a similar phenotype was approximately 500-fold higher than that used in parent drugsensitive KB cells (Figure 1A). These data suggest a 500-fold difference in HAL half-maximal inhibitory concentration $\left(\mathrm{IC}_{50}\right.$ ) between sensitive $\mathrm{KB}$ and resistant KBV20C cells. Compared to previous studies assessing the $\mathrm{IC}_{50}$ of $\mathrm{KB}$ and KBV20C cells using other antimitotic drugs, such as vinblastine, vincristine, paclitaxcel, docetaxcel and colchicines (1-4), KBV20C cells are highly resistant to HAL. Verapamil co-treatment with HAL overcame KBV20C resistance (data not shown or see Figure $3 \mathrm{C}$ and D) confirming that HAL-resistance in KBV20C cells involves the pumping-out ability of the cells associated with $\mathrm{P}$-gp overexpression. It also suggests that HAL is a highly selective substrate pumped-out by P-gp in KBV20C cells. Therefore, we assumed that identifying the sensitization mechanisms of KBV20C cells can provide important information to overcome HAL-resistant phenotypes in the clinic.

FLU is a potential anti-cancer drug and a potential inhibitor of cancer-related Akt pathways (20). First, we tested whether FLU was a substrate for P-gp in drug-resistant KBV20C cells. As shown in Figure 1B, using various concentrations of FLU, we determined that $\mathrm{KB}$ and $\mathrm{KBV} 20 \mathrm{C}$ presented a similar sensitization level, suggesting that FLU is not a substrate of P-gp in drug-resistant KBV20C cells. It also suggests that FLU can be used as an anti-cancer drug in resistant cells, including HAL-resistant cancer cells. Furthermore, we tested whether co-treatment with FLU could sensitize HAL-treated KBV20C cells. As shown in Figure 1C and D, HAL-FLU cotreatment reduced cellular proliferation and increased $\mathrm{G}_{2}$ arrest when compared to treatment with HAL or FLU alone. Collectively, our data show that KBV20C cells are highly resistant to HAL. HAL-FLU co-treatment resulted in reduced proliferation and increased $\mathrm{G}_{2}$ arrest. In addition, FLU single treatment sensitized drug-resistant KBV20C cells as much as $\mathrm{KB}$ cells with a similar $\mathrm{IC}_{50}$. 

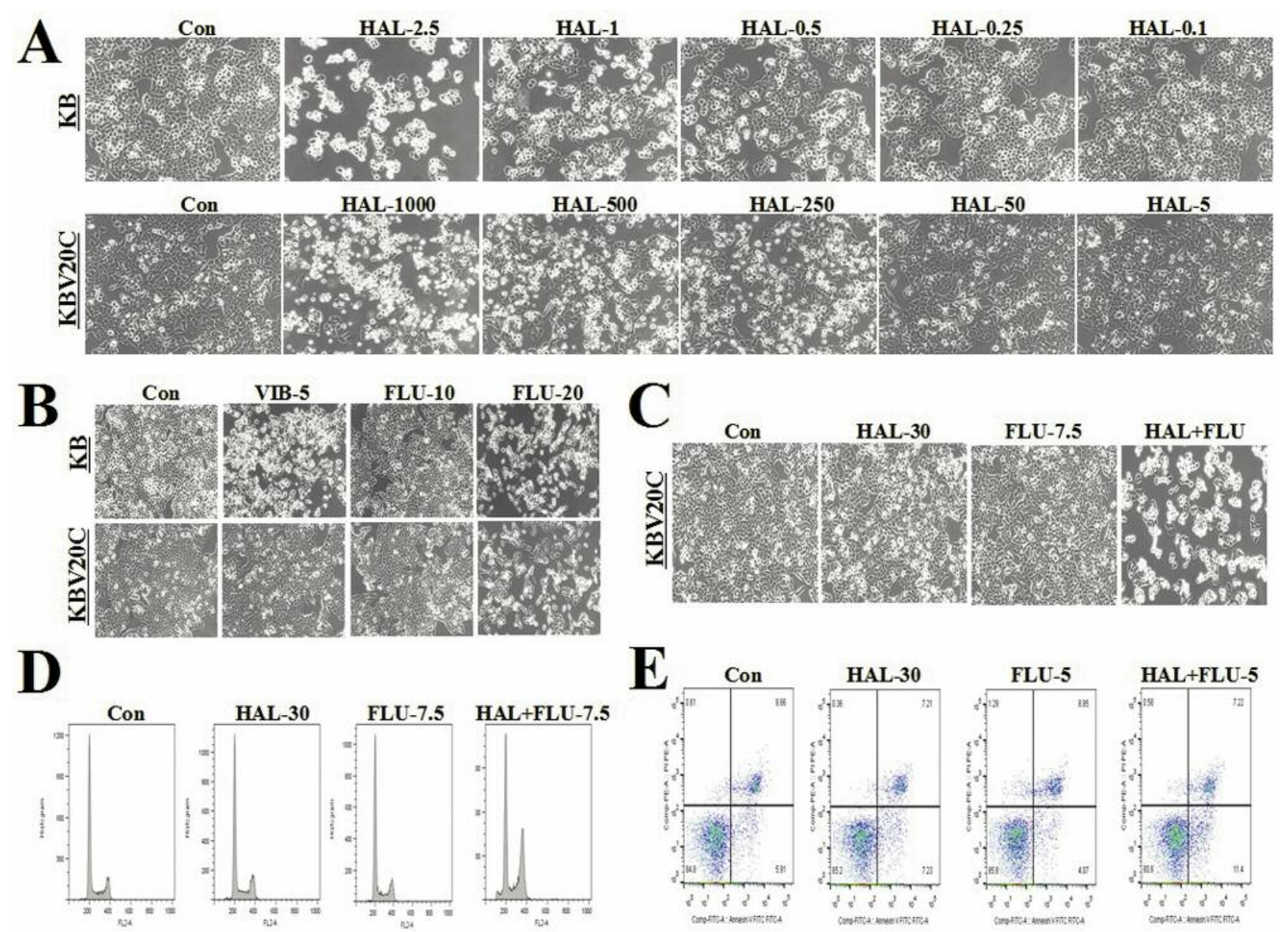

Figure 1. Co-treatment with fluphenazine (FLU) sensitizes highly halaven (HAL)-resistant KBV20C cancer cells via $G_{2}$ arrest. (A) KB and KBV20C cells were grown on 6-well plates and treated with $0.1 \mathrm{ng} / \mathrm{ml} \mathrm{HAL} \mathrm{(HAL-0.1),0.25} \mathrm{ng} / \mathrm{ml} \mathrm{HAL} \mathrm{(HAL-0.25),} 0.5 \mathrm{ng} / \mathrm{ml} \mathrm{HAL} \mathrm{(HAL-0.5),} 1 \mathrm{ng} / \mathrm{ml} \mathrm{HAL}$ (HAL-1), $2.5 \mathrm{ng} / \mathrm{ml} H A L$ (HAL-2.5), $5 \mathrm{ng} / \mathrm{ml} \mathrm{HAL} \mathrm{(HAL-5),} 50 \mathrm{ng} / \mathrm{ml} \mathrm{HAL} \mathrm{(HAL-50),} 250 \mathrm{ng} / \mathrm{ml} H A L$ (HAL-250), 500 ng/ml HAL (HAL-500), $1,000 \mathrm{ng} / \mathrm{ml} \mathrm{HAL}$ (HAL-1000) or 0.1\% DMSO (Con). After 1 day, all cells were observed using an inverted microscope with a 100 magnification. $(B-C) K B$ and KBV2OC cells were grown on 6-well plates and treated with $5 \mathrm{nM}$ vinblastine (VIB), $7.5 \mu M$ fluphenazine (FLU-7.5), 10 $\mu M$ fluphenazine (FLU-10), $20 \mu \mathrm{M}$ fluphenazine (FLU-20), $30 \mathrm{ng} / \mathrm{ml} \mathrm{HAL}$ (HAL-30), $30 \mathrm{ng} / \mathrm{ml}$ HAL with $7.5 \mu M$ FLU (HAL+FLU) or 0.1\% DMSO (Con). After 1 day, all cells were observed using an inverted microscope with a 100 magnification. (D-E) KBV20C cells were grown on $60 \mathrm{~mm}$-diameter dishes and treated with $5 \mu \mathrm{M}$ fluphenazine (FLU-5), $7.5 \mu M$ fluphenazine (FLU-7.5), $30 \mathrm{ng} / \mathrm{ml} \mathrm{HAL} \mathrm{(HAL-30),} 30 \mathrm{ng} / \mathrm{ml} \mathrm{HAL} \mathrm{with}$ $5 \mu M$ FLU (HAL+FLU-5), $30 \mathrm{ng} / \mathrm{ml}$ HAL with $7.5 \mu \mathrm{M} \mathrm{FLU} \mathrm{(HAL+FLU-7.5)} \mathrm{or} \mathrm{0.1 \%} \mathrm{DMSO} \mathrm{(Con).} \mathrm{After} 24$ h, FACS analysis (D) or Annexin V analysis (E) was performed as described in Materials and Methods.

HAL-FLU sensitization of KBV20C involves both apoptosis and P-gp inhibition. We also confirmed that HAL-FLU cotreatment increased apoptosis, which was determined by annexin $\mathrm{V}$ staining (Figure1E). A more detailed analysis of annexin $\mathrm{V}$ showed that higher HAL concentrations $(30 \mu \mathrm{M}$ HAL vs. $50 \mu \mathrm{M}$ HAL) increased apoptosis when combined with FLU (Figure 2A), whereas single treatment using both $30 \mu \mathrm{M}$ HAL and $50 \mu \mathrm{M}$ HAL induced similar levels of apoptosis (Figure 2A). Thus, FLU can dose-dependently recover the anti-cancer ability of HAL.

Especially, the early stage of apoptosis was increased after HAL-FLU co-treatment, suggesting that increased $\mathrm{G}_{2}$ arrest finally resulted in the induction of apoptotic events. Moreover, HAL-FLU co-treatment increased C-PARP production (Figure 2B). When we assessed the levels of important proliferation-related protein or phosphorylation levels $(21,22)$, HAL-FLU co-treatment increased $\mathrm{pRb}$, pHistone $\mathrm{H} 3$ and $\mathrm{pH} 2 \mathrm{AX}$ (Figure 2B), thus suggesting that HAL-FLU co-treatment sensitizes KBV20C cells by reducing proliferation and increasing DNA damaging processes. Collectively, microscopic, FACS, annexin V and western-blot analyses indicated that FLU increased DNA damage and $\mathrm{G}_{2}$ arrest to increase apoptosis in HAL-treated resistant KBV20C cells. 

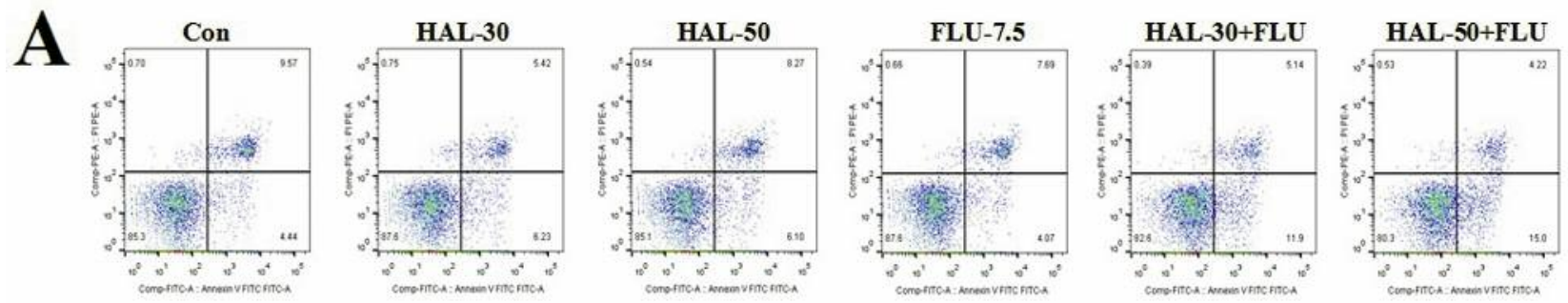

B
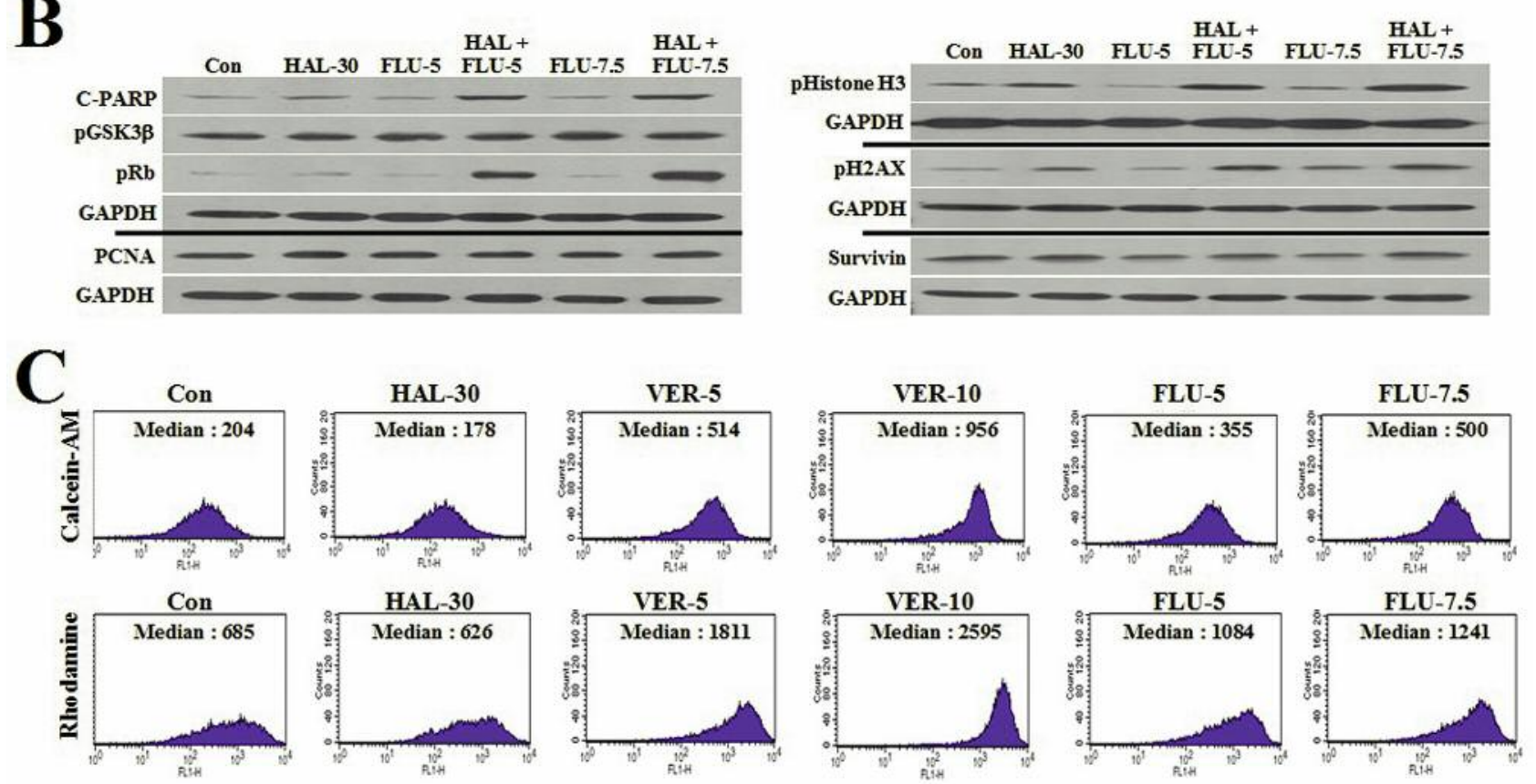

Figure 2. Co-treatment with fluphenazine (FLU) sensitizes highly halaven (HAL)-resistant KBV20C cancer cells through apoptosis, DNA damage and P-gp inhibition. (A) KBV20C cells were grown on $60 \mathrm{~mm}$-diameter dishes and treated with $7.5 \mu \mathrm{M}$ fluphenazine (FLU-7.5), $30 \mathrm{ng} / \mathrm{ml} \mathrm{HAL}$

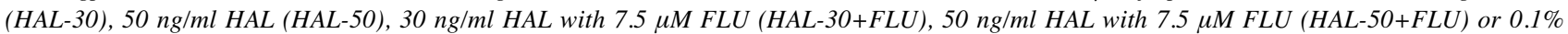
DMSO (Con). After 24 h, Annexin V analysis was performed as described in Materials and Methods. (B) KBV20C cells were grown on 60 mmdiameter dishes and treated with $5 \mu \mathrm{M}$ fluphenazine (FLU-5), $7.5 \mu \mathrm{M}$ fluphenazine (FLU-7.5), $30 \mathrm{ng} / \mathrm{ml} \mathrm{HAL}$ (HAL-30), $30 \mathrm{ng} / \mathrm{ml} \mathrm{HAL} \mathrm{with} 5 \mu \mathrm{M}$ FLU (HAL+FLU-5), $30 \mathrm{ng} / \mathrm{ml}$ HAL with $7.5 \mu \mathrm{M} F \mathrm{CU}(\mathrm{HAL}+F L U-7.5)$ or $0.1 \%$ DMSO (Con). After 24 h, western blot analysis was performed using antibodies against C-PARP, $p G S K 3 \beta, p R b, P C N A$, pHistone H3, pH2AX, survivin and GAPDH. (C) KBV2OC cells were grown on 6-well plates and treated with $30 \mathrm{ng} / \mathrm{ml} H A L$ (HAL-30), $5 \mu \mathrm{M}$ verapamil (VER-5), $10 \mu \mathrm{M}$ verapamil (VER-10), $5 \mu M$ fluphenazine (FLU-5), $7.5 \mu M$ fluphenazine (FLU-7.5) or 0.1\% DMSO (Con). After 24 h, all cells were stained with calcein-AM or rhodamine, as described in Materials and Methods. The stained cells were subsequently examined by using FACS analysis.

We also assessed whether FLU inhibited P-gp. Our results showed that FLU inhibits P-gp activity (Figure 2C). However, P-gp inhibition by FLU was lower than that by a well-known P-gp inhibitor, verapamil (Figure 2C). Thus, FLU can be consider as a weaker P-gp inhibitor. FLU single treatment sensitized both resistant KBV20C and sensitive KB cells (Figure 1B). Thus, HAL-FLU sensitization in KBV20C cells involves both FLU cytotoxic and P-gp inhibitory effects.

FLU-HAL, THIO-HAL and MEF-THIO have similar sensitization effects in highly HAL-resistant KBV20C cells. We previously showed that THIO and MEF can sensitize KBV20C cells by co-treatment with antimitotic drugs $(14,19,23)$. MEF can sensitize HAL-treated KBV20C cells to other types of antimitotic drugs, such as vinblastine, vinorelbine, paclitaxel or docetaxel (14). Here, we tested whether the combination of MEF or THIO with HAL would be more effective than FLU co-treatment. As shown in Figure 3A and B, C-PARP production and microscopic observations indicated that HALMEF, HAL-THIO and HAL-FLU co-treatments had similar sensitization effects, suggesting that MEF, THIO and FLU could similarly sensitize HAL-treated resistant cancer cells. Based on recent drug-screening results, AZA showed selective 

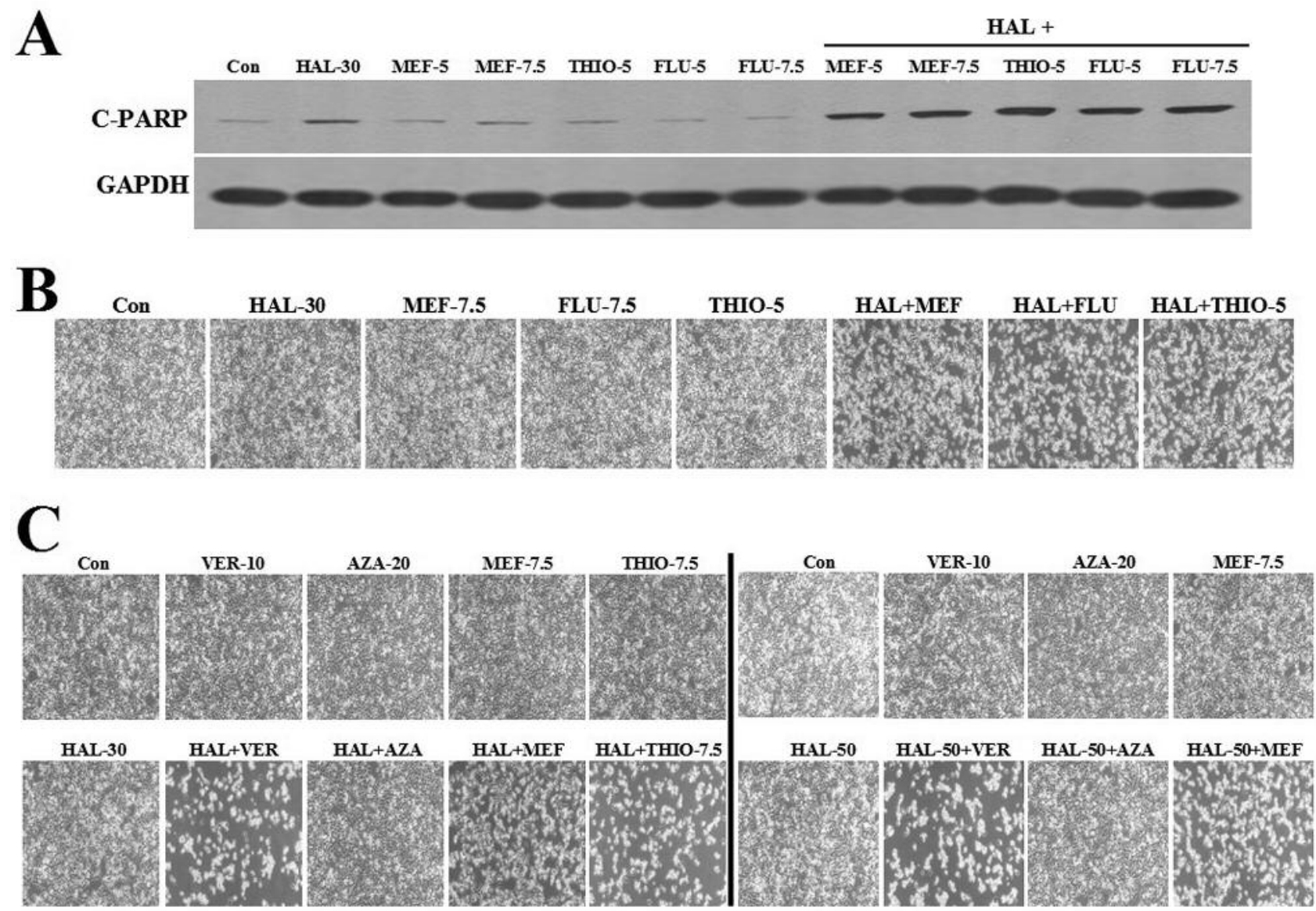

Figure 3. Both thioridazine (THIO) and mefloquine (MEF), but not azathioprine (AZA), increase apoptosis in highly halaven (HAL)-resistant KBV20C cancer cells. (A) KBV20C cells were grown on $60 \mathrm{~mm}$-diameter dishes and treated with $30 \mathrm{ng} / \mathrm{ml} \mathrm{HAL} \mathrm{(HAL-30),} 5 \mu \mathrm{M}$ mefloquine (MEF-5), $7.5 \mu \mathrm{M}$ mefloquine (MEF-7.5), $5 \mu M$ thioridazine (THIO), $5 \mu M$ fluphenazine (FLU-5), $7.5 \mu M$ fluphenazine (FLU-7.5), $30 \mathrm{ng} / \mathrm{ml} \mathrm{HAL}$ with $5 \mu M M E F$ (HAL+MEF-5), $30 \mathrm{ng} / \mathrm{ml}$ HAL with $7.5 \mu \mathrm{M} \mathrm{MEF} \mathrm{(HAL+MEF-7.5),} 30 \mathrm{ng} / \mathrm{ml}$ HAL with $5 \mu \mathrm{M}$ THIO (HAL+THIO-5), $30 \mathrm{ng} / \mathrm{ml}$ HAL with $5 \mu \mathrm{M} F L U$ (HAL+FLU-5), $30 \mathrm{ng} / \mathrm{ml}$ HAL with $7.5 \mu \mathrm{M}$ FLU (HAL+FLU-7.5) or 0.1\% DMSO (Con). After 24 h, western blot analysis was performed using antibodies against C-PARP and GAPDH. (B-C) KBV2OC cells were grown on 6-well plates and treated with $30 \mathrm{ng} / \mathrm{ml} \mathrm{HAL}$ (HAL-30), $50 \mathrm{ng} / \mathrm{ml} H A L$ (HAL-50), $7.5 \mu \mathrm{M}$ mefloquine (MEF-7.5), $7.5 \mu \mathrm{M}$ fluphenazine (FLU-7.5), $5 \mu M$ thioridazine (THIO-5), $7.5 \mu M$ thioridazine (THIO-7.5), $10 \mu \mathrm{M}$ verapamil (VER-10), $20 \mu \mathrm{M}$ azathioprine (AZA-20), $30 \mathrm{ng} / \mathrm{ml} \mathrm{HAL}$ with $7.5 \mu \mathrm{M}$ MEF (HAL+MEF), $30 \mathrm{ng} / \mathrm{ml} \mathrm{HAL}$ with $7.5 \mu M$ FLU (HAL+FLU), $30 \mathrm{ng} / \mathrm{ml}$ HAL with $5 \mu \mathrm{M}$ THIO (HAL+THIO-5), $30 \mathrm{ng} / \mathrm{ml}$ HAL with $10 \mu M$ VER (HAL+VER), $30 \mathrm{ng} / \mathrm{ml} \mathrm{HAL}$ with $20 \mu M$ AZA (HAL+AZA), $30 \mathrm{ng} / \mathrm{ml} \mathrm{HAL} \mathrm{with} 7.5 \mu \mathrm{M}$ THIO (HAL+THIO-7.5), $50 \mathrm{ng} / \mathrm{ml} \mathrm{HAL} \mathrm{with} 10 \mu \mathrm{M}$ VER (HAL-50+VER), $50 \mathrm{ng} / \mathrm{ml}$ HAL with $20 \mu \mathrm{M} \mathrm{AZA}(\mathrm{HAL}-50+\mathrm{AZA}), 50 \mathrm{ng} / \mathrm{ml} \mathrm{HAL}$ with $7.5 \mu \mathrm{M} \mathrm{MEF}$ (HAL-50+MEF) or 0.1\% DMSO (Con). After 1 day, all cells were observed using an inverted microscope with a 50 magnification.

sensitization effects on cancer stem cells as MEF and THIO (13). Therefore, we tested whether AZA also increased the sensitivity of HAL-treated KBV20C cells. However, AZA did not increase the sensitivity of HAL-treated KBV20C cells (Figure 3C), whereas MEF and THIO sensitized HAL-treated KBV20C cells. These data suggest that P-gp-overexpressing resistant KBV20C cells respond differently to drugs compared to other cancer stem cells or the observed effects are specific to this cancer cell line. As shown in Figure 3C, verapamil presented high sensitization effects when combined with HAL, suggesting that P-gp inhibition is the most effective method to overcome HAL-resistance in cancer cells.
We did not observe differences in the sensitization effects among HAL-FLU, HAL-THIO and HAL-MEF using microscopic observations. We then used FACS analysis to observe which combination was the best to sensitize HALresistant KBV20C cells. As shown in Figure 4A and B, HALTHIO presented a much better sensitization effect than HALMEF and HAL-FLU. HAL-MEF induced a similar $\mathrm{G}_{2}$ arrest and pre- $\mathrm{G}_{1}$ region when compared to HAL-FLU (Figure 4A and $\mathrm{B}$ ). These results suggest that THIO has better sensitization effect on HAL-resistant cancer cells and that the best effect can be obtain by using lower concentration of THIO when combined with HAL. We also speculate that its 

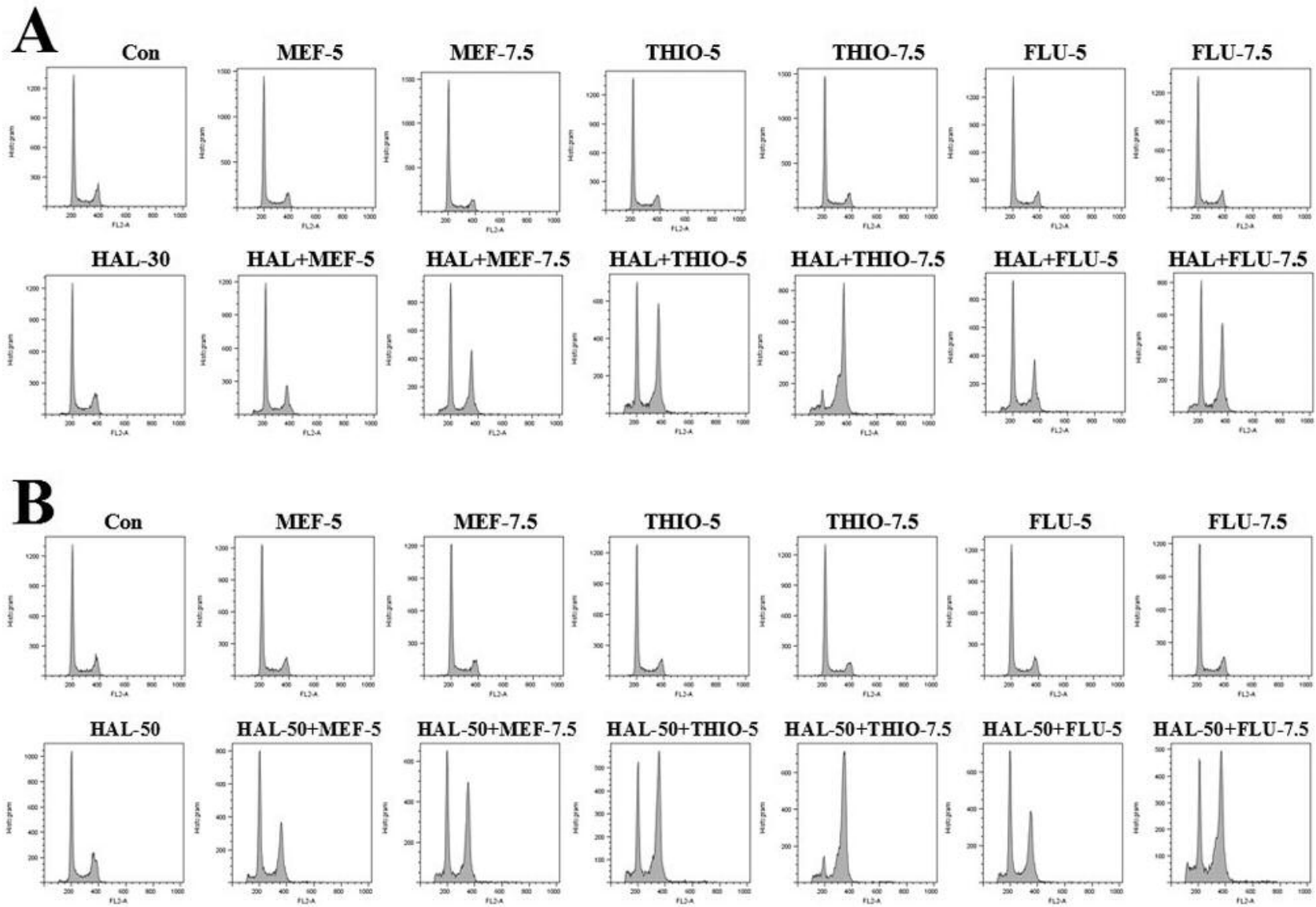

Figure 4. Thioridazine (THIO) is more efficient than fluphenazine ( $F L U)$ and mefloquine (MEF) in sensitizing highly halaven (HAL)-resistant KBV20C cells. (A-B) KBV20C cells were grown on $60 \mathrm{~mm}$-diameter dishes and treated with $30 \mathrm{ng} / \mathrm{ml} H A L$ (HAL-30), $50 \mathrm{ng} / \mathrm{ml} \mathrm{HAL} \mathrm{(HAL-50),} 5 \mu \mathrm{M}$ mefloquine (MEF-5), $7.5 \mu M$ mefloquine (MEF-7.5), $5 \mu M$ THIO (THIO-7.5), $7.5 \mu$ M thioridazine (THIO-7.5), $5 \mu M$ fluphenazine (FLU-5), $7.5 \mu M$ fluphenazine

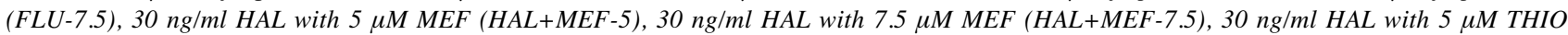
(HAL+THIO-5), $30 \mathrm{ng} / \mathrm{ml}$ HAL with $7.5 \mu \mathrm{M}$ THIO (HAL+THIO-7.5), $30 \mathrm{ng} / \mathrm{ml}$ HAL with $5 \mu M$ FLU (HAL+FLU-5), $30 \mathrm{ng} / \mathrm{ml} \mathrm{HAL} \mathrm{with} 7.5 \mu M$ FLU (HAL+FLU-7.5), $50 \mathrm{ng} / \mathrm{ml} H A L$ with $5 \mu M$ MEF (HAL-50+MEF-5), $50 \mathrm{ng} / \mathrm{ml} \mathrm{HAL} \mathrm{with} 7.5 \mu M \mathrm{MEF}$ (HAL-50+MEF-7.5), $50 \mathrm{ng} / \mathrm{ml} \mathrm{HAL}$ with $5 \mu \mathrm{M}$ THIO (HAL-50+THIO-5), $50 \mathrm{ng} / \mathrm{ml}$ HAL with $7.5 \mu \mathrm{M}$ THIO (HAL-50+THIO-7.5), $50 \mathrm{ng} / \mathrm{ml}$ HAL with $5 \mu \mathrm{M}$ FLU (HAL-50+FLU-5), $50 \mathrm{ng} / \mathrm{ml}$ HAL with $7.5 \mu M$ FLU (HAL-50+FLU-7.5) or 0.1\% DMSO (Con). After 24 h, FACS analysis was performed as described in Materials and Methods.

toxicity can be lowered by using reduced THIO concentrations in combination with HAL. Collectively, highly resistant KBV20 cells can be sensitized by co-treatment with repositioned drugs, such as FLU, THIO and MEF.

\section{Discussion}

HAL has been recently developed and is especially promising for the treatment of patients for whom anti-cancer drugs previously failed $(5-8,24)$. Additional studies focusing on the mechanisms of HAL sensitization and toxicity would be beneficial for future studies examining the utility of HAL as a chemotherapeutic agent in various cancer types. Therefore, we aimed to increase our understanding of the mechanisms associated with sensitization of HAL-resistant KBV20C cancer cells that overexpress P-gp.

HAL-resistant KBV20C cells can be sensitized at HAL concentrations almost 500-fold higher than those required for parent sensitive KB cells, suggesting that HAL is effectively pumped out by $\mathrm{P}$-gp. Considering that our previous studies showed less than 10-fold differences when using other antimitotic drugs $(14,17-19,23,25)$, these results also suggest that overexpressed P-gp can be an important mechanism of HAL resistance to avoid its toxicity. Since it is expected that HAL-treated cancer patients will ultimately develop a resistance to HAL, we assumed that our studies using highly HAL-resistant cancer cells could provide insight for the treatment of HAL-resistant cancer patients. In order to identify 
sensitization mechanisms, conditions or drugs, we tested repositioned drugs. Repositioned drugs, already used in the clinic, can be quickly applied without further toxic tests (26, 27). Based on a literature search and our previous studies (14, 17, 19, 23, 25), we tested whether HAL-treated KBV20C cells can be sensitized to HAL when co-treated with promising repositioned drugs, such as FLU, MEF, THIO and AZA.

We previously tested the sensitization effects of THIO and MEF $(14,19,23)$. In this study, the effects of co-treatment using FLU and AZA were analyzed for the first time. Since both drugs showed similar sensitization effects in cancer screening and in the literature $(13,28,29)$, we tested them and compared their effects to those of THIO and MEF. The cancer-sensitizing ability of FLU has been demonstrated in various cancer models $(9-12,28,29)$, suggesting that it has potential as a chemotherapeutic agent. Single FLU treatment presented a similar $\mathrm{IC}_{50}$ between $\mathrm{KB}$ and KBV20C cells, indicating that FLU cannot be a target of P-gp. It also shows that single FLU treatment can be used in drug-resistant cancer cells without increasing FLU concentrations. Furthermore, we demonstrated that HAL-FLU co-treatment reduced cellular proliferation and increased G2 arrest in highly HAL-resistant KBV20C cells. Based on microscopic analysis, FACS analysis, annexin $\mathrm{V}$ analysis and western-blot analysis, we concluded that early stage apoptosis was increased by HALFLU co-treatment via increased $\mathrm{G}_{2}$ arrest and reduced proliferation. We hypothesize that FLU stimulates $G_{2}$ arrest by increasing DNA damage, reducing cellular proliferation, thereby increasing apoptosis in HAL-treated resistant KBV20C cells. We also confirmed that FLU prevents the pumping-out ability of P-gp, acting as a weak P-gp inhibitor. Considering that single FLU treatment presented similar sensitization effects in $\mathrm{P}$-gp-overexpressing resistant KBV20C and sensitive parent KB cells, we conclude that FLU sensitization mechanism involves both apoptosis and Pgp inhibition in HAL-treated resistant KBV20C cells.

THIO and MEF were previously shown to sensitize antimitotic drugs'-treated KBV20C cells (14, 19, 23). A repositioned drug, AZA, was recently shown to sensitize cancer stem cells or resistant cancer cells (13). Interestingly, the study showed that AZA, MEF and THIO selectively sensitized specific types of cancer stem cells (13). Therefore, we tested whether AZA, MEF and THIO could sensitize HAL-treated resistant KBV20C cells. FLU, MEF and THIO sensitized HAL-treated KBV20C cells, but AZA did not, suggesting that $\mathrm{P}$-gp-overexpressing resistant KBV20C cells are different from the previously studied cancer stem cells. Furthermore, we assessed which drug presented the best sensitization effect in combination with HAL. Using FACS analysis, we observed that HAL-THIO combination treatment resulted in a better $\mathrm{G}_{2}$ arrest and pre- $\mathrm{G}_{1}$ region effects than HAL-MEF and HAL-FLU, indicating that THIO may be the best combination partner for HAL-resistant cancer treatment.
Altogether, our results show that highly HAL-resistant KBV20 cells can be killed by co-treatment with the repositioned drugs, FLU, THIO and MEF. Since these repositioned drugs are already used in clinical settings, the urgent need for pharmacological treatments of HALresistant cancers can be efficiently addressed and these drugs may be used to treat HAL-resistant patients at a relatively faster pace.

\section{Conflicts of Interest}

The Authors declare no conflicts of interest.

\section{Acknowledgements}

The Authors thank Ae-Ran Choi and Ju-Hwa Kim for help in technical supports and preparation of the manuscript. This research was supported by the National Research Foundation of Korea (NRF) funded by the Korean government (NRF-2016R1A4A1011189).

\section{References}

1 Jordan MA and Wilson L: Microtubules as a target for anticancer drugs. Nat Rev Cancer 4: 253-265, 2004.

2 McGrogan BT, Gilmartin B, Carney DN and McCann A: Taxanes, microtubules and chemoresistant breast cancer. Biochim Biophys Acta 1785: 96-132, 2008.

3 Matsuo K, Bond VK, Im DD and Rosenshein NB: Prediction of chemotherapy response with platinum and taxane in the advanced stage of ovarian and uterine carcinosarcoma: A clinical implication of in vitro drug resistance assay. Am J Clin Oncol 33: 358-363, 2010

4 Yang H and Dou QP: Targeting apoptosis pathway with natural terpenoids: Implications for treatment of breast and prostate cancer. Curr Drug Targets 11: 733-744, 2010.

5 Dell'Ova M, De Maio E, Guiu S, Roca L, Dalenc F, Durigova A, Pinguet F, Bekhtari K, Jacot W and Pouderoux S: Tumour biology, metastatic sites and taxanes sensitivity as determinants of eribulin mesylate efficacy in breast cancer: Results from the ERIBEX retrospective, international, multicenter study. BMC cancer 15: 659, 2015.

6 Laughney AM, Kim E, Sprachman MM, Miller MA, Kohler RH, Yang KS, Orth JD, Mitchison TJ and Weissleder R: Single-cell pharmacokinetic imaging reveals a therapeutic strategy to overcome drug resistance to the microtubule inhibitor eribulin. Sci Transl Med 6: 261ra152, 2014.

7 Aogi K, Iwata H, Masuda N, Mukai H, Yoshida M, Rai Y, Taguchi K, Sasaki Y and Takashima S: A phase II study of eribulin in Japanese patients with heavily pretreated metastatic breast cancer. Ann Oncol 23: 1441-1448, 2012.

8 Dybdal-Hargreaves NF, Risinger AL and Mooberry SL: Eribulin mesylate: mechanism of action of a unique microtubule-targeting agent. Clin Cancer Res 21: 2445-2452, 2015.

9 De Preter K, De Brouwer S, Van Maerken T, Pattyn F, Schramm A, Eggert A, Vandesompele J and Speleman F: Meta-mining of neuroblastoma and neuroblast gene expression profiles reveals candidate therapeutic compounds. Clin Cancer Res 15: 36903696, 2009. 
10 Hwang MK, Min YK and Kim SH: Calmodulin inhibition contributes to sensitize TRAIL-induced apoptosis in human lung cancer H1299 cells. Biochem Cell Biol 87: 919-926, 2009.

11 Jaszczyszyn A, Gasiorowski K, Swiatek P, Malinka W, CieslikBoczula K, Petrus $J$ and Czamik-Matusewicz B: New fluphenazine analogues as inhibitors of P-glycoprotein in human lymphocyte cultures. Contem Oncol 16: 332-337, 2012.

12 Yang JM, Sullivan GF, Makhey DB, LaVoie EJ and Hait WN: Inhibitory effect of alkylating modulators on the function of $\mathrm{P}$ glycoprotein. Oncol Res 9: 477-484, 1997.

13 Sachlos E, Risueno RM, Laronde S, Shapovalova Z, Lee JH, Russell J, Malig M, McNicol JD, Fiebig-Comyn A, Graham M, Levadoux-Martin M, Lee JB, Giacomelli AO, Hassell JA, Fischer-Russell D, Trus MR, Foley R, Leber B, Xenocostas A, Brown ED, Collins TJ and Bhatia M: Identification of drugs including a dopamine receptor antagonist that selectively target cancer stem cells. Cell 149: 1284-1297, 2012.

14 Choi AR, Kim JH, Woo YH, Kim HS and Yoon S: Anti-malarial drugs primaquine and chloroquine have different sensitization effects with antimitotic drugs in resistant cancer cells. Anticancer Res 36: 1641-1648, 2016.

15 Hwang JW, Cho H, Lee JY, Jeon Y, Kim SN, Lee SJ, Bae GU, Yoon S, Jeon R and Kim YK: The synthetic ajoene analog SPA3015 induces apoptotic cell death through crosstalk between NF-kappaB and PPARgamma in multidrug-resistant cancer cells. Food Chem Toxicol 96: 35-42, 2016.

$16 \mathrm{Kim}$ NH, Kim SN, Oh JS, Lee S and Kim YK: Antimitotic potential of 7-diethylamino-3(2'-benzoxazolyl)-coumarin in 5fluorouracil-resistant human gastric cancer cell line snu620/5-fu. Biochem Biophy Res Commun 418: 616-621, 2012.

17 Choi AR, Jo MJ, Jung MJ, Kim HS and Yoon S: Selenate specifically sensitizes drug-resistant cancer cells by increasing apoptosis via $\mathrm{G} 2$ phase cell cycle arrest without P-GP inhibition. Eur J Pharmacol 764: 63-69, 2015.

18 Choi AR, Jung MJ, Kim JH and Yoon S: Co-treatment of Salinomycin Sensitizes AZD5363-treated Cancer Cells Through Increased Apoptosis. Anticancer Res 35: 4741-4747, 2015.

19 Choi AR, Kim JH and Yoon S: Thioridazine specifically sensitizes drug-resistant cancer cells through highly increase in apoptosis and p-gp inhibition. Tumour Biol 35: 9831-9838, 2014.

20 Rho SB, Kim BR and Kang S: A gene signature-based approach identifies thioridazine as an inhibitor of phosphatidylinositol-3'kinase (PI3K)/AKT pathway in ovarian cancer cells. Gynecol Oncol 120: 121-127, 2011.
21 Choi AR, Kim JH and Yoon S: Sensitization of cancer cells through reduction of total AKT and downregulation of salinomycininduction of pAKT, pGSK3beta, pTSC2, and p4EBP1 by cotreatment with MK-2206. Biomed Res Int 2014: 295760, 2014.

$22 \mathrm{Kim}$ JH, Choi AR, Kim YK, Kim HS and Yoon S: Low amount of salinomycin Greatly increases AKT activation, but reduces activated p70S6K levels. Int J Mol Sci 14: 17304-17318, 2013.

$23 \mathrm{Kim}$ JH, Choi AR, Kim YK and Yoon S: Co-treatment with the anti-malarial drugs mefloquine and primaquine highly sensitizes drug-resistant cancer cells by increasing P-gp inhibition. Biochem Biophys Res Commun 441: 655-660, 2013.

24 Ribeiro JT, Macedo LT, Curigliano G, Fumagalli L, Locatelli M, Dalton M, Quintela A, Carvalheira JB, Manunta S, Mazzarella L, Brollo J and Goldhirsch A: Cytotoxic drugs for patients with breast cancer in the era of targeted treatment: back to the future? Ann Oncol 23: 547-555, 2012.

$25 \mathrm{Kim}$ JH, Chae M, Choi AR, Sik Kim H and Yoon S: SP600125 overcomes antimitotic drug-resistance in cancer cells by increasing apoptosis with independence of P-gp inhibition. Eur J Pharmacol 723: 141-147, 2014.

26 Clark KB: New therapeutic bearings for repositioned drugs. Curr Top Med Chem 13: 2281-2282, 2013.

27 Pantziarka P and Cairns L: Recycling existing drugs for cancer therapy: delivering low cost cancer care. Ecancermedicalscience 8: ed40, 2014.

28 Cieslik-Boczula K, Swiatek P, Jaszczyszyn A, Zawilska P, Gasiorowski K, Malinka W and Kohler G: Phase separation in phosphatidylcholine membrane caused by the presence of a pyrimidine analogue of fluphenazine with high anti-multidrugresistance activity. J Phys Chem B 118: 3605-3615, 2014.

29 Qi L and Ding Y: Potential antitumor mechanisms of phenothiazine drugs. Sci China Life Sci 56: 1020-1027, 2013.
Received August 11, 2016

Revised September 1, 2016

Accepted September 2, 2016 